December 2013

\title{
LIS Professionals: Providing Free \& Accessible Information
}

Adrienne Mathewson

desertrhythm@gmail.com

Follow this and additional works at: https://scholarworks.sjsu.edu/ischoolsrj

Part of the Library and Information Science Commons

\section{Recommended Citation}

Mathewson, A. (2013). LIS Professionals: Providing Free \& Accessible Information. School of Information Student Research Journal, 3(2). https://doi.org/10.31979/2575-2499.030201 Retrieved from https://scholarworks.sjsu.edu/ischoolsrj/vol3/iss2/1

This article is brought to you by the open access Journals at SJSU ScholarWorks. It has been accepted for inclusion in School of Information Student Research Journal by an authorized administrator of SJSU ScholarWorks. For more information, please contact scholarworks@sjsu.edu. 


\section{LIS Professionals: Providing Free \& Accessible Information}

\section{Keywords}

open-source, library and information professionals, scholarly journals

\section{About Author}

Adrienne Mathewson is the Editor-in-Chief of the Student Research Journal and a graduate student at San José State University, School of Library and Information Science. She works as an Independent Information Professional and Managing Editor of a community newspaper. 
As we wind down the publishing process for our Fall 2013 issue and I complete my first term as Editor-in-Chief, I realize that publishing a scholarly journal is a tremendous undertaking and learning experience for the Editorial Team. The Student Research Journal is a studentgoverned scholarly journal, which means that as LIS students, we are reviewing our fellow graduate students' manuscripts. This review process is an excellent learning tool for the editors, and we hope that we are helping our peers learn the importance of producing quality scholarly research during this process.

Here at SRJ, we receive submissions from LIS students around the world and the editors face the difficult challenge of critically evaluating each manuscript through the rigorous doubleblind peer review process. Only two manuscripts made it through the peer-review process for this second issue of the third volume, which is a testament to the thoroughness of our editorial team. The submissions covered a diverse subject range within the LIS profession. Our editorial team members reviewed papers on academic librarianship, young adult literature, historical research and electronic record keeping, among others. The diversity of research reflects the rapidly changing world of the LIS professional and serves as a reminder of the value of a MLIS degree to the information professional.

In this issue of the Student Research Journal, we present two very different papers as Julia Wells examines the stereotype of the female librarian within the social context of film, and Tony Brooke provides a thorough examination of open source integrated library systems. Yet even with these two seemingly diverse subjects, a theme emerges that, despite the rapidly changing role of the librarian from the stereotypical stern female librarian to the technologically hip librarian of today, librarians still protect the right to free and accessible information to the public.

Wells' article "The Female Librarian in Film: Has the Image Changed in 60 Years?" examines the image of the female librarian over a sixty- year span as depicted in popular movies. "Has the representation of the librarian changed to depict a more positive image of the librarian?" she asks. Or are librarians still seen through the lens of the prevailing stereotype of an older, unmarried woman with her hair in a bun? Wells examines various movie scenes in which people visit libraries seeking information, studying and conducting other library activities to determine how librarians are portrayed by the media.

Tony Brooke introduces his research paper on "Open Source Integrated Library Systems in Public Libraries" by stating, "Increasingly the face of the public library is no longer a bespectacled librarian behind an orderly desk" and discusses how the electronic age affects the way information is delivered in both presentation and content. He states that one of the most important choices that information professionals have to make is deciding which integrated library system (ILS) to use. Brooke explains that until recently, commercial ILS systems were the only option; however, free and open source software (FOSS) is now a viable option. He discusses the advantages of FOSS within the library system stating that collaboration between librarians and open source developers is a natural fit as both share the trait of being "obsessive about sharing information".

As an open-source journal, SRJ proudly continues the traditional role of providing free and accessible information to all. Our goal is to advance scholarship in the library and information science field by providing a forum for LIS graduate students to publish their works through a double-blind peer review. At the same time, the editorial team members use their experience at the journal to increase their scholarly research, writing skills and strategic reading skills under the skillful guidance of our Faculty Advisor, Anthony Bernier. 
In conclusion, I'd like to offer my thanks and congratulations to our graduating team members and a special thank-you to the Managing Editor for this issue, Barnaby Hughes. I also thank the faculty of the School of Library and Information Science at San José State University, and the SRJ Editorial Advisory Board for their continued support in publishing graduate scholarship. Lastly, I thank the excellent technical support team at bepress Digital Commons. I welcome our new team members to this exciting opportunity to govern our very own Student Research Journal. We are already hard at work producing another excellent publication for Spring 2014.

Julia Wells is a graduate student in the MLIS program at SJSU School of Library \& Information Science. She received her BA in Psychology and Women's Studies from McGill University, in Montreal, Canada.

Tony Brooke is a master's degree candidate at the School of Library and Information Science at San José State University. His research has investigated media asset management and audiovisual metadata. He has been an audio engineer in San Francisco since 1992. 